\title{
The English Economic Term 'Human Capital' and Its Semantic Field in Scientific Discourse
}

\author{
Yulia A. Filyasova \\ Saint-Petersburg University of Management Technologies and Economics \\ Lermontovsky prospect, 44A, Saint-Petersburg, Russia 190103
}

\begin{abstract}
Recently, human capital (HC) has acquired special relevance in response to digital economy development. A semantic study of $\mathrm{HC}$ is significant for its linguistic description and practical purposes of teaching business English to students, specializing in economics and management. The aims of the research were to analyze dictionary definitions, compare them with contextual interpretations, and identify syntagmatic relations and lexical collocability of the term $\mathrm{HC}$ in scientific discourse. 340 article titles and their abstracts from 18 journals on economics and management served as the material for the research. The methods included continuous sampling, analysis of contextual relations, semantic classification, and componential analysis. The results of definition analysis showed that $\mathrm{HC}$ has intangible components of meaning and partly overlaps with resources, in opposition to capital which has monetary nature. Contextual interpretations disclose more semantic aspects of HC. Monetary relations and production factors make it closer to capital. Considerable attention is paid to $\mathrm{HC}$ formation and measurement. Terms, related to $\mathrm{HC}$, embrace a wide variety of phenomena from almost all functional areas of business, which indicate the importance of $\mathrm{HC}$ for sustainable development, increasing profit and competitiveness. Semantic classification of collocations shows that $\mathrm{HC}$ is considered at the personal, organizational and national levels. The most frequent syntagmatic sequences include $H C+N, N+$ Prep. $+H C$, and $A d j .+H C$. Objective valency type: $V+H C$ is more common than subjective: $H C+V$. The most frequent collocations are $H C$ accumulation, $H C$ investments, and the role of $H C$.
\end{abstract}

Key words: Business English, scientific discourse, definition analysis, componential analysis, lexical collocability, syntagmatic relations, valency, linguistic worldview

\section{Introduction}

Communicative systems, such as language, are viewed as models for understanding real-life processes [1. P. 9] and developing a linguistic worldview. From a linguistic standpoint, human capital (HC) is a language unit, which can be studied at different levels of language structure: phonetics, lexicology, syntax, etc. In this paper, semantics is in the focus of attention. A linguistic analysis will contribute to gaining an insight into the substance of the term HC. Semantically, it belongs to the category of abstract words, which implies, as I.M. Kobozeva suggests, description of their significative meaning and application of such methods as synonymous paraphrase and collocability analysis [2. P. 85].

\section{Филясова Ю.А., 2019.}

(i) This work is licensed under a Creative Commons Attribution 4.0 International License https://creativecommons.org/licenses/by/4.0/ 
A linguistic method, studying systemic functional relationships in a language, is semantic field theory, introduced by Jost Trier [3]. The theory was further developed by V.G. Admoni, A.V. Bondarko, G.S. Shchur and other linguists. Each semantic field includes a system of types and classes, variants of a certain semantic category, related to various formal means of their realization [4. P. 11]. A certain semantic category the one which unites various linguistic units and determines their interaction - forms the basis of any functional semantic field [5. P. 35; 6. P. 6]. Identification of invariant units and referring them to particular speech segments determines the boundaries of the unit variation in a semantic field [7. P. 21].

A lexical unit is part of a language - a semiotic system of a particular type; hence, a lexical unit is a sign. Following A.A. Ufimtseva, a complete semiotic description of a lexical sign means conducting an analysis of its semes (paradigmatics), semantic derivation (epidigmatics), and their functioning in speech (syntagmatics) [8. P. 129]. I.M. Kobozeva suggests adding semantic oppositions and corresponding features to description of lexical units and their semantic fields [9].

According to N.Y. Shvedova, a linguistic environment, in which a word functions, has a tripartite character: firstly, the word belongs to a particular lexical class and has a number of lexical oppositions; secondly, it acquires various linear syntagmatic connections in a text; and thirdly, the word functions in different communicative and pragmatic contexts. In other words, the word is part of a class, text and context [10. P. 383].

The ability of a word to connect with other linguistic units is also called valency the term introduced by S.D. Katsnel'son [11] and L. Ten'er [12]. Understanding syntagmatic connections of a semantic field reveals inherent relationships between semantics of classes and their realizations in speech. As noted by V.N. Denisenko, interpretation of any fragment of reality as a linguistically organized "semantic space" seems to be an effective and valid method of world cognition [13. P. 23]. A number of recent research papers are devoted to this field of study $[7 ; 14-21]$.

The aims of this research are to differentiate the semantic field of the term HC from related lexical units, compare dictionary definitions of $\mathrm{HC}$ with its contextual interpretations, determine syntagmatic relations and lexical collocability of the term $\mathrm{HC}$ in scientific economic discourse. Description of the linguistic view of HC based on the obtained results has theoretical value. Research article titles and the related abstracts, containing the term $\mathrm{HC}$, from journals, devoted to economic and managerial sciences, along with the correspondent dictionary definitions, are considered as the object of the analysis. Notably, research articles reflect the latest views, some of which might later become semantic components in dictionary definitions of $\mathrm{HC}$.

The practical relevance lies in the fact that the results can be used in the practice of teaching business English to students specializing in economics and management. It is worth noting that scientific discourse is characterized by multiple modes of semiotic communication, including spoken, written, representational, inscriptional, and symbolic, among others. The range of semiotic communicative forms shows wide variation and is often alien to science students' ways communicating in others aspects of their lives [22. P. 321]. Consequently, drawing students' attention to scientific papers will improve their reading skills in the language of science [23], enhance their knowledge of English [24] and develop competencies in professional areas. 


\section{Material}

The resources included 18 journals [26-43], related to the areas of economy and human resource management (HRM): Economics Letters (47 articles), The Economics of Education Review (42), Economic Modelling (35), The Journal of Human Capital (32), The Journal of Intellectual Capital (23), Labour Economics (22), Journal of Management (21), Review of Development Economics (19), The Journal of Human Resources (15), The Journal of Comparative Economics (15), The Journal of Monetary Economics (13), Strategic Management Journal (13), International Economic Review (12), Journal of Economic Surveys (11), The Human Resource Management Journal (8), Global Business Review (5), The Human Resource Management Review (4), The Journal of Finance (3). The corpus contained 340 article titles and the related abstracts, 44800 words in total. 894 occurrences of the term HC were analyzed.

\section{Methodology}

Initially, the articles were continuously selected by the key word: HC; then word combinations were classified into categories on the basis of their valency and contextual meanings. Taking into consideration the fundamentals of semantic analysis mentioned above, the following methods were used:

1. dictionary definitions of the term HC were analyzed in combination with capital and resources in order to compare their individual semantic components;

2. contextual definitions (31) and related economic phenomena (142) were identified;

3. syntagmatic relations of $\mathrm{HC}$ and collocations were revealed in the left and right contexts:

3.1. $\mathrm{HC}+\mathrm{N}(344$ occurrences $)$

3.2. $\mathrm{N}+$ Prep. $+\mathrm{HC}(187$ occ.)

3.3. Adj. $+\mathrm{HC}(91$ occ.)

3.4. N's+HC (22 occ.)

3.5. $\mathrm{V}+\mathrm{HC}(51$ occ. $)$

3.6. $\mathrm{HC}+\mathrm{V}(16$ occ. $)$

3.7. HC+Prep. $+\mathrm{N}(10$ occ. $)$

As a result of the analysis, the frequency of collocations with $H C$ was determined.

\section{Results}

\section{Dictionary definitions}

From an economic perspective, $\mathrm{HC}$ is highly valuable in the modern society, though it is a multifaceted complex economic term, difficult for measuring and accounting. It differs from other forms of capital and is related to the field of HRM. The term contains the notion capital as a constituent element; and simultaneously, it has human nature.

Let us compare semantic components of the terms $H C$, capital, and resources, given in dictionaries [44-47]. The term $\mathrm{HC}$ is a unique intangible notion, whose denotative meaning completely coincides neither with capital nor resources (Table 1). The principle distinctions of the term $\mathrm{HC}$ are as follows. 
Differential semantic components of the terms /

Дифференциальные семантические компоненты терминов

\begin{tabular}{|c|c|c|}
\hline \multirow[t]{3}{*}{ HC } & \multicolumn{2}{|c|}{$\begin{array}{l}\text { Semes: people, employees, skills, knowledge, experience, resources, talents, abilities, intelli- } \\
\text { gence, training, judgment, wisdom, a form of wealth, motivation, health, intellectual capital, } \\
\text { competencies, source of creativity and innovativeness }\end{array}$} \\
\hline & \multicolumn{2}{|c|}{$\begin{array}{l}\text { Specificity: not reflected in financial statements; incorporated in the organization's procedures } \\
\text { and structure }\end{array}$} \\
\hline & $\begin{array}{l}\text { Predicates: (people) have; } \\
\text { be possessed; be owned; } \\
\text { be available }\end{array}$ & $\begin{array}{l}\text { Goals: accomplish goals; yield fulfillment and satisfaction to } \\
\text { the possessor; impart the ability to change }\end{array}$ \\
\hline \multirow[t]{3}{*}{ Capital } & \multicolumn{2}{|c|}{ Semes: money, property, possessions, assets, wealth, factors of production } \\
\hline & \multicolumn{2}{|c|}{ Specificity: not itself in the process } \\
\hline & $\begin{array}{l}\text { Predicates: be used; } \\
\text { be available; be invested }\end{array}$ & $\begin{array}{l}\text { Goals: to earn more money; for producing more wealth; for } \\
\text { starting a new business; for increasing financial strength; for } \\
\text { development or investment; to generate income; to create } \\
\text { goods or services }\end{array}$ \\
\hline \multirow[t]{2}{*}{ Resources } & \multicolumn{2}{|c|}{$\begin{array}{l}\text { Semes: money, workers, equipment, qualities, skills, possession, economic or productive } \\
\text { factor, means, land, labor, capital, energy, entrepreneurship, information, expertise, } \\
\text { management, time }\end{array}$} \\
\hline & $\begin{array}{l}\text { Predicates: (people) have; } \\
\text { be used; be required }\end{array}$ & $\begin{array}{l}\text { Goals: to help an institution or a business; for dealing with } \\
\text { problems; to accomplish an activity; to undertake an enterprise; } \\
\text { to achieve desired outcome }\end{array}$ \\
\hline
\end{tabular}

Firstly, HC has mainly intangible nature, including human resources (HR). Capital embraces monetary notions. Capital means wealth, while human capital is only a form of wealth. Gaining $\mathrm{HC}$ does not mean gaining direct monetary benefits. The term resources is semantically the widest, including both tangible and intangible semes. Among other similarities, both capital and resources are regarded as factors of production. It is worth mentioning that according to the current economic paradigm, $\mathrm{HC}$ is viewed as a factor of production in the era of digital economy, virtual reality, computeraided manufacturing and artificial intelligence development [25]. That places $\mathrm{HC}$ on a par with capital and resources. However, it does not deprive $\mathrm{HC}$ of its abstract quality.

Secondly, the attainment of $\mathrm{HC}$ is regarded as an end in itself [47], - whereas the terms capital and resources are non-finite elements, in effect. This is also proven by the predicate: be used does not appear in the semantics of HC (Table 1).

Thirdly, $\mathrm{HC}$ is not reflected in financial statements, in contrast to capital and resources. Nevertheless, it is incorporated in the organization's procedures and structure.

As for the goals mentioned in each definition, capital is aimed at deriving material and financial profit, such as money, goods, services, or business expansion; in other words, certain material tangible results. However, in relation to $\mathrm{HC}$ and resources, more abstract or intangible outcome is mentioned (Table 1).

On balance, $\mathrm{HC}$ has more similarities with the term resources, as it incorporates both tangible and intangible semantic components, in contrast to capital, which is obviously tangible.

It is worth mentioning here that the related term human resources is much narrower in meaning since it denotes only the department of an organization which deals with finding new employees, keeping records about all the organization's employees, and helping them with any problems [44; 46]. The alternative term to HR is personnel [47]. 


\section{Contextual definitions and related phenomena}

As noted by I.M. Kobozeva, synonymous paraphrase is an integral part of semantic analysis, focused on abstract words [2. P. 85]. For this reason, contextual explanations of $\mathrm{HC}$ were found in research abstracts. They give a more detailed and broader view, and define $\mathrm{HC}$ as a multifaceted concept, determinant of economic growth, indicator of productivity, even as a factor of wage disparities (Table 2). They also have interpretations which directly match dictionary definitions: knowledge, skills, capabilities, and experience. Additionally, contexts expand the term up to education and professional training.

At the level of HR departments, HC is associated with employee capability, satisfaction, and commitment. Strategically, $\mathrm{HC}$ is a source of competitive advantage. A number of contextual definitions point at the connection of $\mathrm{HC}$ with resources and assets (Table 2).

Table 2 / Таблица 2

Contextual definitions of $\mathrm{HC} /$

Контекстные определения человеческого капитала (ЧК)

\begin{tabular}{|l|l|}
\hline the engine of growth & tenure, investment experience, education \\
a key driver of economic development & professional training, gender \\
- mey determinant of wages & an important component of intellectual capital \\
- complex input & - a key valuable resource \\
a multidimensional construct & most important asset \\
- explanation for health-related wage disparities & an asset to be invested in \\
\hline
\end{tabular}

Contrasted phenomena include a wide range of notions, ranging from personal to national issues, though differences are sometimes blurred and the phenomena can be attributed to more than one level. As can be seen from Tb. 3, HC being intangible by definition, in its generalized representation influences many aspects of human life, the prosperity of companies and national interests.

At the personal level, $\mathrm{HC}$ is related to the following aspects: the number of children in a family, the existence of family itself, family types, people's physical and mental state, financial and social differences among people, employment patterns, career perspectives, and work-life balance, among others.

The organizational level embraces almost all functional areas of business activity; not only immediately HRM, but also finance, marketing, research and development, strategic planning, information technologies, production.

At the national level, the term $\mathrm{HC}$ concerns a long list of fundamental aspects of economic development, social life, demographics, urbanizations, education, migration, technological development, and others. 
Economic phenomena related to $\mathrm{HC} /$

Table 3 / Таблица 3

Экономические явления, соотносимые с ЧК

\begin{tabular}{|c|c|c|}
\hline Personal level & Organizational level & National level \\
\hline 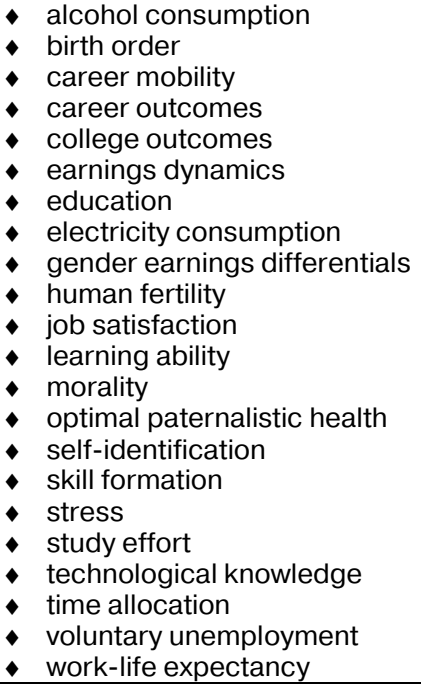 & 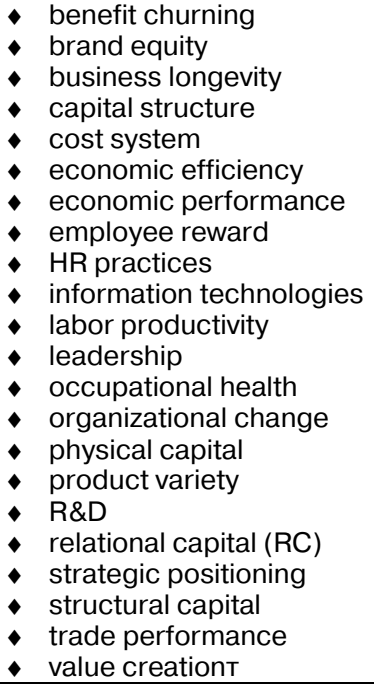 & 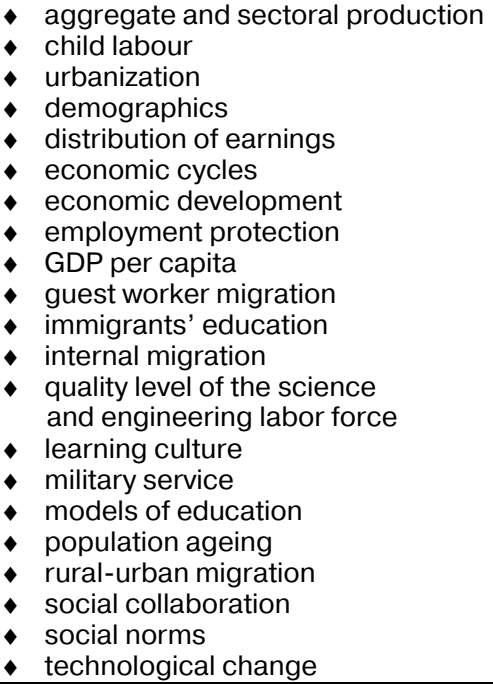 \\
\hline
\end{tabular}

\section{Syntagmatic relations and collocability}

\section{1. $H C+N$}

These syntagmatic relations are the most numerous. The most frequent collocations are $H C$ accumulation and $H C$ investments; less frequent are $H C$ formation, $H C$ theory, $H C$ approach, $H C$ endowments, and $H C$ measurement.

Semantic categories of $\mathbf{H C}+\mathbf{N} /$

Table 4 / Таблица 4

\section{Семантические категории ЧК+N}

\begin{tabular}{|c|c|c|}
\hline $\mathrm{HC}$ theory & Economic aspects & $\mathrm{HC}$ accumulation \\
\hline $\begin{array}{l}\text { HC analysis } \\
\text { HC analytics } \\
\text { HC concept } \\
\text { HC definitions } \\
\text { HC explanation } \\
\text { HC queld } \\
\text { HC research postulates } \\
\text { HC research, } 2 \\
\text { HC theorists } \\
\text { HC theory, } 16 \\
\end{array}$ & $\begin{array}{l}\text { HC disparity (rural-urban) } \\
\text { HC distribution } \\
\text { HC migration } \\
\text { HC scarcity, } 2 \\
\text { HC sector, } 3 \\
\text { HC sectoral productivities } \\
\text { HC technolog } 6 \\
\text { HC transition } \\
\text { HC-intensive industries, } 2 \\
\end{array}$ & $\begin{array}{l}\text { HC accumulation, } 77 \\
\text { HC augmentation } \\
\text { HC building } \\
\text { HC consequences of violence } \\
\text { HC enhancement } \\
\text { HC formation, } 23 \\
\text { HC gaps } \\
\text { HC growth, } 3 \\
\text { HC transmission } \\
\end{array}$ \\
\hline Monetary aspects & $\mathrm{HC}$ measurement & Organizational issues \\
\hline $\begin{array}{l}\text { HC acquisition, } 3 \\
\text { HC cost } \\
\text { HC depreciation } \\
\text { HC endowments, } 10 \\
\text { HC investment decisions, } 3 \\
\text { HC investment risk } \\
\text { HC investment, } 58 \\
\text { HC premium } \\
\text { HC rates } \\
\text { HC returns, } 2 \\
\text { HC risks } \\
\text { HC subsidy, } 2\end{array}$ & $\begin{array}{l}\text { HC accounting } \\
\text { HC approach, } 11 \\
\text { HC background } \\
\text { HC complementarities } \\
\text { HC evaluation } \\
\text { HC indicators, } 2 \\
\text { HC inequality, } 2 \\
\text { HC items (in financial statements) } \\
\text { HC quality differences } \\
\text { HC valuation, } 2 \\
\text { HC value measurement }\end{array}$ & $\begin{array}{l}\text { HC allocation } \\
\text { HC assets } \\
\text { HC depletion, } 2 \\
\text { HC differences } \\
\text { HC employment mode } \\
\text { HC good } \\
\text { HC information } \\
\text { HC intangibles } \\
\text { HC management practices } \\
\text { HC prodicies, } 4 \\
\text { HC production technology } \\
\text { HC resources, } 3 \\
\text { HC-intensive firms }\end{array}$ \\
\hline
\end{tabular}


The semantic field embraces the following semantic categories: HC theory, HC accumulation, HC measurement, monetary issues, organizational and economic issues (Table 4). Interestingly, it includes monetary aspects - not present in dictionary definitions.

\section{2. $($ Adj. + ) $N+$ Prep. $+H C$}

One of the most frequent collocations in this category is the role of HC (39 occ.). Let us consider the semantics of these syntagmatic relations.

Conceptual aspects of $\mathrm{HC}$ reflect the boundaries of the term, including the structure of the notion, origins, forms, types, levels, parameters, cognitive constituents, and others. The accumulation of HC implies its sources, development, accumulation, transmission, transferability, and stock, among others. Monetary features are exposed by such aspects as acquisition, assessment, estimation, value drivers, measurement, cost, investment, endowments, return, obsolescence and depreciation. At the organizational level, HC acquires specific features, such as concentration, specification, qualitative indicators, performance, proportion, inimitability, etc. (Table 5).

Table 5 / Таблица 5

Semantic categories of N+Prep.+HC /

Семантические категории $\mathrm{N}+\mathrm{Prep} .+4 \mathrm{~K}$

\begin{tabular}{|c|c|c|c|}
\hline $\mathrm{HC}$ theory & $\mathrm{HC}$ accumulation & Monetary aspects & Organizational level \\
\hline 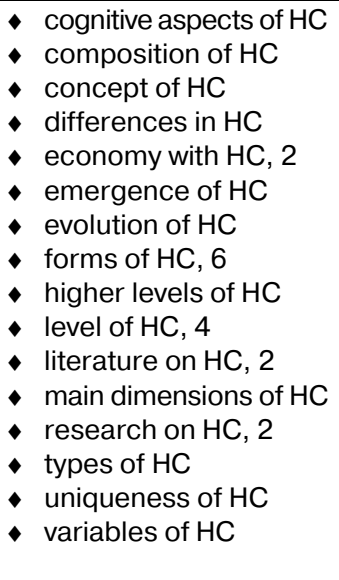 & $\begin{array}{l}\text { accumulation of } \mathrm{HC}, 3 \\
\text { of } \mathrm{HC} \\
\text { - } \text { development of } \mathrm{HC}, 3 \\
\text { formation of } \mathrm{HC}, 2 \\
\text { growth of } \mathrm{HC} \\
\text { intergenerational } \\
\text { transmission of } \mathrm{HC}, 2 \\
\text { - negative proxies of } \mathrm{HC} \\
\text { - } \text { pow proxies for HC } \\
\text { - } \text { troductions of } \mathrm{HC} \\
\text { - } \text { transmission of } \mathrm{HC} \\
\text { transferability } \mathrm{HC} \\
\text { transmission of } \mathrm{HC}, 8 \\
\text { woman's stock of } \mathrm{HC}\end{array}$ & 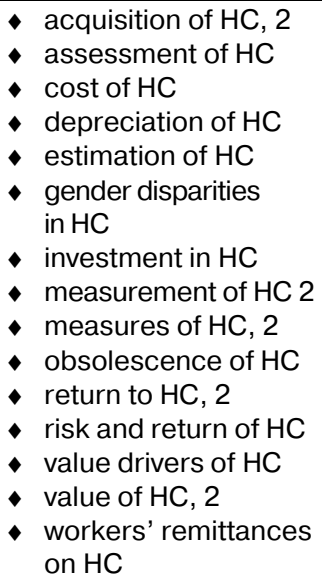 & 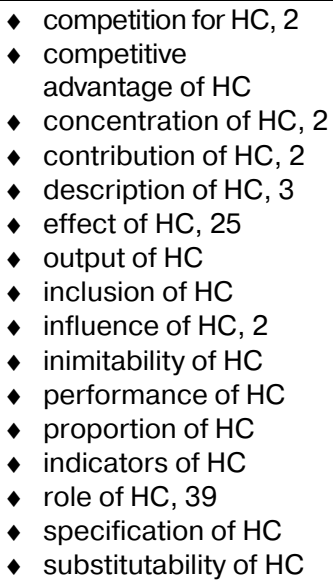 \\
\hline
\end{tabular}

\subsection{Adj. $+H C$}

The most frequently used collocation is specific HC (25 occ.).

Semantic categories include specificity, origin, relation to company, amount, professionalism, age, national origin, and a few individual word collocations:

Specificity: specific, 25; differential; general, 3; firm-specific, 3; occupation-specific; industry-specific; research-specific; country-specific; sector-specific; colleague-specific.

Origin: maternal; parental; low parental; personal; endogenous; educational; inherited; dynastic; individual level, 2; individual; collective; child.

Company: entrepreneurial; organizational, 2; managerial; strategic; unit-level; hierarchical; upper-echelon executive. 
Amount: higher; high; abundant; more; less; scarce.

Professionalism: high-skilled; skilled; experience-based; advanced; highly trained.

Age: age-structured; modern, 5; existing.

National origin: local; foreign; origin-country.

Miscellaneous: heterogeneous; risky; rival; valuable; language; inalienable; the latent variable.

\subsection{N's+HC}

The scope of its semantics comprises three large areas:

People: children's, 3; parents'; descendants'; individuals', 3; women 's, 2.

Company: organization 's; firm 's; manager's; executives'; directors '; founders'; inventors'.

Nation: Russia's; nation's; immigrants'; academic's.

\section{5. $\mathrm{V}+\mathrm{HC}$}

The verbal structure with the term HC clearly shows logical sequence of activities, performed at the organizational level: $\mathrm{HC}$ accumulation, analysis, management and gaining monetary profit (Table 6).

Table 6 / Таблица 6

Semantic categories of $\mathrm{V}+\mathrm{HC} /$

Семантические категории $\mathrm{V}+4 \mathrm{~K}$

\begin{tabular}{|c|c|c|c|}
\hline $\mathrm{HC}$ accumulation & $\mathrm{HC}$ analysis & $\mathrm{HC}$ management & Monetary aspects \\
\hline $\begin{array}{ll} & \text { accumulate } \mathrm{HC}, 2 \\
\text { acquire } \mathrm{HC}, 4 \\
\text { develop } \mathrm{HC}, 3 \\
\text { enhance } \mathrm{HC}, 2 \\
\text { improve } \mathrm{HC}, 2 \\
\text { increase } \mathrm{HC} \\
\text { invest in HC, } 5\end{array}$ & $\begin{array}{ll}\text { examine HC } \\
\text { classify the HC } \\
\text { of a company } \\
\text { analyze HC } \\
\text { explore HC } \\
\text { focus on HC } \\
\text { investigate } \mathrm{HC} \\
\text { study HC }\end{array}$ & 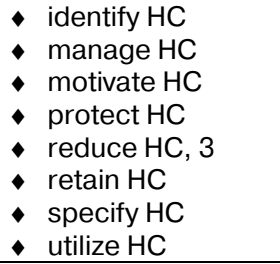 & $\begin{array}{ll} & \text { assess HC } \\
\text { - } & \text { evaluate HC } \\
\text { isolate HC } \\
\text { (from expenses) } \\
\text { measure HC, } 4 \\
\text { obtain HC } \\
\text { transform HC } \\
\text { value HC }\end{array}$ \\
\hline
\end{tabular}

\section{6. $H C+V$}

The vast semantic areas include 'people', 'company' and 'economy'. The verbs in the right context are increase, augment, influence, affect, impacts, play a role, contribute to, facilitate, stimulate, interact with, respond to, dampen, result in. Though three times less frequent, they partly coincide with those in the left context (Table 6). The objects in the sequence $\mathrm{HC}+\mathrm{V}+\mathrm{O}$ include performance, investments, growth, income, and some others:

People: $\mathrm{HC}$ investments increase lifetime income; HC plays an important role in performance of individual-level $\mathrm{HC}$; HC increases the risk of overbidding; $\mathrm{HC}$ affects laid-off workers' occupation choices; HC increases the opportunity cost of crime from foregone work and expected costs associated with incarceration.

Company: HC influences the firm's decisions; HC stimulates investment in physical capital; HC augments labor productivity and also facilitates the transition to skilled employment; HC impacts organizational performance; HC result in superior performance; $\mathrm{HC}$ interacts with incentives; firms' HC influences investments in occupational health and safety. 
Economy: HC contributes to rise in economic growth; the different levels of $\mathrm{HC}$ affect countries differently; HC responds to global opportunities; HC dampens responses of young workers to transitory tax changes.

$$
\text { 3.7. } H C+\text { Prep. }+N
$$

Three areas are covered:

People: the HC of black soldiers, 2; the HC of natives; the HC of children, 3.

Company: HC in service organizations; HC of family firms; HC for hiring and promotions.

Economy: $H C$ in the new economy; (the effects of) HC on developmental potential; $H C$ in various industries.

\section{Conclusion}

To summarize, the English economic term $\mathrm{HC}$ can be referred to the category of abstract nouns on the basis of its dictionary definitions and the semantic field presented in research articles. Despite the fact that $\mathrm{HC}$ contains the word capital, its meaning is scarcely similar to capital - mainly a financial term. $\mathrm{HC}$ is closer to the term resources due to the abstract components of its semantic meaning. Additionally, the term $\mathrm{HC}$ is much wider than HR - the latter are only attributed to the activities performed by personnel departments in organizations.

The analysis of the semantic field of $\mathrm{HC}$ in scientific discourse revealed a wider understanding of the term than that presented in dictionary definitions. That is explained by the fact that research articles on economy and management contain results of practical studies and attempts to identify, measure, estimate, evaluate, determine the cost and, finally, derive profit from $\mathrm{HC}$ in business practice. In research articles, $\mathrm{HC}$ is analyzed at three major levels: personal, organizational and national (Fig. 1.).

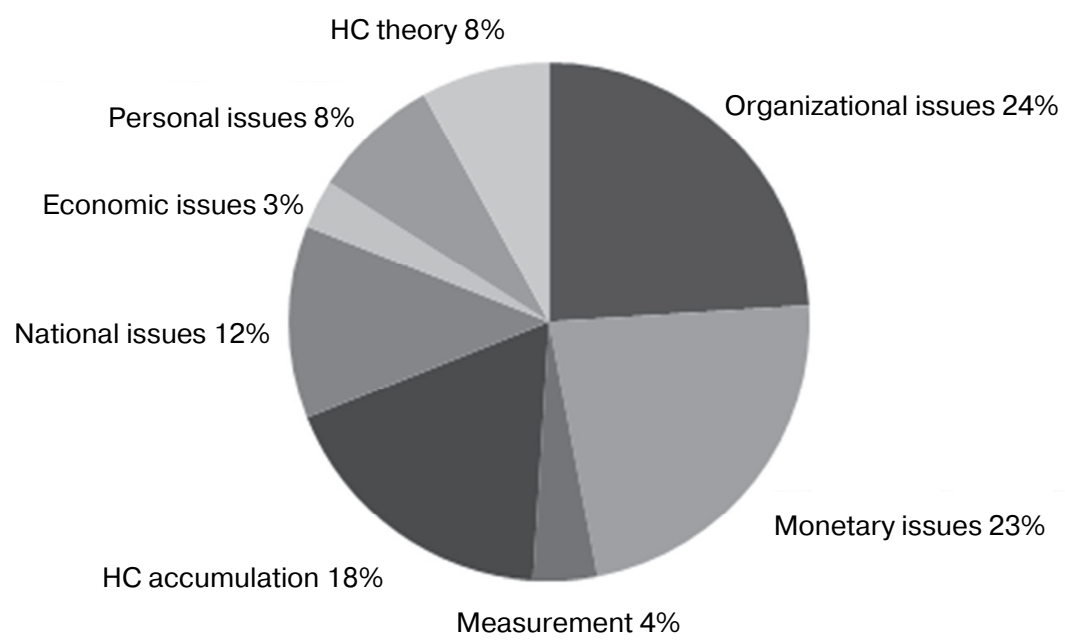

Fig. 1. The semantic field of $\mathrm{HC}$ in scientific discourse /

Рис. 1. Семантическое поле ЧК в научном дискурсе 
The importance of $\mathrm{HC}$ becomes clear as a result of studying contextual definitions and the related phenomena. The semantic field of the term shows that ii affects individuals' health, family formation, education, career, income. At the organizational level, HC influences almost all functional areas of business activity. Most crucially, effective approaches to HC contribute to higher productivity, return on investments, business performance, and, ultimately, competitiveness. Similarly, the levels of economy and nation are equally dependent on $\mathrm{HC}$ accumulation. Additionally, $\mathrm{HC}$ affects social collaboration, norms, hierarchy, gender disparities and other issues.

Noteworthily, in contrast to dictionary definitions, contextual interpretations refer to monetary aspects of the term $\mathrm{HC}$ and attempts to measure and incorporate it into financial statements. Moreover, HC accumulation, formation, development, enhancement and improvement as a result of education, training and intergenerational transmission could also widen the dictionary definitions.

Syntagmatic relation types differ in frequency: the most numerous are $\mathrm{HC}+\mathrm{N}$ and $\mathrm{N}+$ Prep. $+\mathrm{HC}$. Twice as numerous are Adj. $+\mathrm{HC}$. The type of valency where HC acts as an object: $\mathrm{V}+\mathrm{HC}$ is more common than $\mathrm{HC}+\mathrm{V}$, where it functions as a subject.

The attributes specifying HC denote a range of characteristics: professional skills, the origin of $\mathrm{HC}$, age, specificity, relation to organizational structure, the amount, even language, and others.

The most frequent lexical collocations are as follows: $H C$ accumulation, $H C$ investments, HC formation, $H C$ theory, $H C$ approach, $H C$ endowments, $H C$ measurement, the role of $H C$, and specific $H C$.

As the conducted research shows, the term HC is rapidly developing, partly due to the emergence of new technologies, and requires further research.

\section{История статьи:}

Дата поступления: 1.06.2019

Дата приема в печать: 1.08.2019

\section{Article history:}

Received: 1.06 .2019

Accepted: 1.08.2019

\section{References}

1. Halliday M.A.K., Martin J.R. (1993). Writing science: literacy and discursive power. Pittsburgh.

2. Kobozeva I.M. (2000). Linguistic semantics. Moscow. (In Russ.)

3. Trier, J. (1931). Der deutsche Wortschatz im Sinnbezirk des Verstandes, Ph.D. diss. Bonn.

4. Shchur G.S. (2009). The theory of field in linguistics. $3^{\text {rd }}$ ed. Moscow. (In Russ.)

5. Admoni V.G. (1964). Fundamentals of grammar theory. Moscow. (In Russ.)

6. Bondarko A.V. (1999). Fundamentals of functional grammar. Saint-Petersburg. (In Russ.)

7. Abramov V.P., Abramova G.A. (2017). Structural and Functional Approaches to Semantic Fields Analysis. RUDN Journal of Russian and Foreign Languages Research and Teaching, 15 (1), 9-25. (In Russ.)

8. Ufimtseva A.A. (1986). Lexical meaning. Moscow. (In Russ.)

9. Kobozeva I.M. (2016), Lexical items in a grammar: functions, categorization, constraints. Russian Language Abroad, 3, 51-55. (In Russ.)

10. Shvedova N.Y. (2005). The Russian language. Moscow. (In Russ.)

11. Katsnel'son S.D. (1948). About grammatical category. Bulletin of Leningrad State University, 2, 114-134. (In Russ.)

12. Ten'er, L. (1988). Fundamentals of structural syntax. Moscow. (In Russ.) 
13. Denisenko V.N. (2011). Semantic field: Syntagmatics and paradigmatics. RUDN Journal of Language Studies, Semiotics and Semantics, 2, 18-24. (In Russ.)

14. Averina A.V. (2019). Valency of modal words and particles in German. Bulletin of Moscow Region State University. Series: Linguistics, 2, 43-52. (In Russ.)

15. Filyasova Yu.A. (2019). Effectiveness vs. efficiency: an analysis of valency and collocability in a technical context. RUDN Journal of Language Studies, Semiotics and Semantics, 10 (1), 187-196.

16. Kasimova G.K. (2013). Comparative analysis of semantic structure of cognate derivatives. RUDN Journal of Linguistics, 4, 93-101. (In Russ.)

17. Mukhachyova I.V. (2019). Semantic valencies of the verb rasstegnut' (to unbutton) and ineffability of semantic valencies. Rhema. Rema, 1, 48-64. (In Russ.)

18. Paymakova E.A. (2010). Some semantic aspects of the English antonymous adjectives (a study of HEAVY and LIGHT). RUDN Journal of Language Studies, Semiotics and Semantics, 1, 21-27. (In Russ.)

19. Rice S., Newman J. (2018). A Corpus Investigation of English Cognition Verbs and their Effect on the Incipient Epistemization Physical Activity Verbs. Russian Journal of Linguistics, 22 (3), $560-580$.

20. Trufanova I.V. (2017). Lexicographic portrait of a pronoun other. RUDN Journal of Language Studies, Semiotics and Semantics, 8(3), 509-518. (In Russ.)

21. Yudina N.V. (2014). Terminology of kinship relations in the Russian language discourse of the 21st century. The Scientific Opinion, 9, 13-23. (In Russ.)

22. Kelly G.J. (2014). Discourse practices in science learning and teaching. Handbook of research on science education, vol. II. New York. P. 321-336.

23. McComas W.F. (2014). Scientific Discourse (Rhetoric of Science). The Language of Science Education. Rotterdam.

24. Filyasova Yu.A. (2015). Continuous and end-of-module assessment system modelling for second language communicative competence evaluation. RUDN Journal of Russian and Foreign Languages Research and Teaching, 4, 220-223. (In Russ.)

25. Kostin A.V. (2018). From informational to digital society. Human capital in the format of digital economy: Conference proceedings. 16 Febr. 2018. Moscow. P. 72-80. (In Russ.)

\section{Journals / Журналы}

26. Economics Letters. URL: https://www.journals.elsevier.com/economics-letters (accessed: 7.04.2019).

27. The Economics of Education Review. URL: https://www.journals.elsevier.com/economics-ofeducation-review (accessed: 10.04.2019).

28. Economic Modelling. URL: https://www.journals.elsevier.com/economic-modelling (accessed: 12.04.2019).

29. The Journal of Human Capital. URL: https://www.journals.uchicago.edu/toc/jhc (accessed: 15.04.2019).

30. The Journal of Intellectual Capital. URL: https://www.emeraldinsight.com/loi/jic (accessed: 18.04.2019).

31. Labour Economics. URL: https://www.journals.elsevier.com/labour-economics (accessed: 20.04.2019).

32. Journal of Management. URL: https://journals.sagepub.com/home/jom (accessed: 24.04.2019).

33. Review of Development Economics. URL: https://onlinelibrary.wiley.com/journal/14679361 (accessed: 25.04.2019).

34. The Journal of Human Resources. URL: http://jhr.uwpress.org/ (accessed: 28.04.2019)

35. The Journal of Comparative Economics. URL: https://www.journals.elsevier.com/journal-ofcomparative-economics (accessed: 1.05.2019). 
36. The Journal of Monetary Economics. URL: https://www.journals.elsevier.com/journal-ofmonetary-economics (accessed: 3.05.2019).

37. Strategic Management Journal. URL: https://onlinelibrary.wiley.com/journal/10970266 (accessed: 5.05.2019).

38. International Economic Review. URL: https://onlinelibrary.wiley.com/journal/14682354 (accessed: 7.05.2019).

39. Journal of Economic Surveys. URL: https://onlinelibrary.wiley.com/journal/14676419 (accessed: 10.05.2019).

40. The Human Resource Management Journal. URL: https://onlinelibrary.wiley.com/journal/ 17488583 (accessed: 12.05.2019).

41. Global Business Review. URL: https://journals.sagepub.com/home/gbr (accessed: 14.05.2019).

42. The Human Resource Management Review. URL: https://www.journals.elsevier.com/humanresource-management-review (accessed: 15.05.2019).

43. The Journal of Finance. URL: https://onlinelibrary.wiley.com/journal/15406261 (accessed: 16.05.2019).

\title{
Dictionaries / Словари
}

44. Cambridge Dictionary. URL: https://dictionary.cambridge.org/ (accessed: 18.05.2019).

45. ENCYCLOPÆDIA BRITANNICA. URL: https://www.britannica.com/ (accessed: 19.05.2019).

46. Macmillan Dictionary. URL: https://www.macmillandictionary.com/ (accessed: 21.05.2019).

47. The Business Dictionary. URL: http://www.businessdictionary.com/ (accessed: 24.05.2019).

\section{Английский экономический термин «человеческий капитал» и его семантическое поле в научном дискурсе}

\author{
Ю.А. Филясова \\ Санкт-Петербургский университет технологий управления и экономики \\ Лермонтовский проспект, 44А, г. Санкт-Петербург, Россия, 190103
}

\begin{abstract}
Аннотация. В настоящее время человеческий капитал (ЧК) приобретает особое значение в ответ на развитие цифровой экономики. Семантический анализ ЧК имеет теоретическую ценность для лингвистического описания экономического термина и практическую значимость для преподавания делового английского языка студентам экономических и управленческих направлений подготовки. Целями исследования были проанализировать словарные дефиниции, сопоставить их с контекстными определениями и выявить синтагматические отношения и лексическую сочетаемость термина ЧК в научном дискурсе. Материалом послужили 340 названий научных статей и их аннотаций из 18 журналов по экономике и менеджменту. Методы исследования включали сплошную выборку, анализ контекстных отношений, семантическую классификацию и компонентный анализ. В результате анализа дефиниций было выявлено, что ЧК имеет абстрактные компоненты значения и частично совпадает с термином pecypcbl, но не с термином капитал, имеющим монетарную природу. Контекстные определения раскрывают больше аспектов значения термина ЧК. Монетарные отношения и факторы производства сближают его с капиталом. Большое внимание в научном дискурсе уделяется формированию и измерению ЧК. Экономические термины, контекстуально связанные с ЧК, охватывают широкое разнообразие явлений почти из всех функциональных областей
\end{abstract}


бизнеса. Они указывают на важность ЧК для устойчивого развития, увеличения прибыли и конкурентоспособности. Семантическая классификация словосочетаний показывает, что ЧК рассматривается на личностном, организационном и национальном уровнях. Наиболее частотные синтагматические последовательности включают $H C+N, N+P r e p .+H C$ и $A d j .+H C$. Объектная валентная связь термина ЧК: $V+H C$ - более распространенная, чем субъектная: $H C+V$. Наиболее употребительными словосочетаниями оказались HC accumulation, $H C$ investments и the role of $H C$.

Ключевые слова: деловой английский язык, научный дискурс, анализ дефиниций, компонентный анализ, лексическая сочетаемость, синтагматические отношения, валентность, языковая картина мира

\section{Библиографический список}

1. Халлидей М.А.К., Мартин Дж.Р. Письменная наука: грамотность и сила дискурса. Питтсбург, 1993.

2. Кобозева И.М. Лингвистическая семантика. М., 2000.

3. Трир Ж. Исследование словарного состава немецкого языка в смысловом поле понимания: Дисс. ... д.ф.н. Бонн, 1931.

4. Щур Г.С. Теории поля в лингвистике. М., 2009.

5. Адмони В.Г. Основы теории грамматики. М., 1964.

6. Бондарко А.В. Основы функциональной грамматики. СПб., 2001.

7. Абрамов В.П., Абрамова Г.А. Структурный и функциональный подходы к анализу семантического поля // Вестник Российского университета дружбы народов. Серия: Русский и иностранные языки и методика их преподавания. 2017. Т. 15. nо 1. С. $9-25$.

8. Уфимиева А.А. Лексическое значение. М., 1986.

9. Кобозева И.М. Лексика в грамматике - функции, категоризация, ограничения // Русский язык за рубежом. 2016. nо 3. С. 51-55.

10. Шведова Н.Ю. Русский язык. М., 2005.

11. Каџнельсон С.Д. О грамматической категории // Вестник Ленинградского государственного университета. 1948. по 2. С. 114-134.

12. Теньер Л. Основы структурного синтаксиса. М., 1988.

13. Денисенко В.Н. Синтагматика и парадигматика семантического поля // Вестник Российского университета дружбы народов. Серия: Теория языка. Семиотика. Семантика. 2011. no 2. C. $18-24$.

14. Аверина А.В. Валентность модальных слов и частиц в немецком языке // Вестник Московского государственного областного университета. Серия: Лингвистика. 2019. nо 2. C. $43-52$.

15. Филясова Ю.А. Effectiveness vs. efficiency: анализ валентности и сочетаемости в техническом контексте // Вестник Российского университета дружбы народов. Серия: Теория языка. Семиотика. Семантика. 2019. Т. 10. по 1. С. 187-196.

16. Касимова Г.К. Сопоставительный анализ семантической структуры однокоренных дериватов // Вестник Российского университета дружбы народов. Серия Лингвистика. 2013. no 4. C. $93-101$.

17. Мухачёва И.В. Семантические валентности глагола расстегнуть и явление невыразимости валентностей // Rhema. Рема. 2019. no 1. С. 48-64.

18. Паймакова E.A. Некоторые семантические особенности английских прилагательных антонимов (на материале прилагательных heavy_light) // Вестник Российского университета дружбы народов. Серия Теория языка. Семиотика. Семантика, 2010. no 1. С. 21-27.

19. Райс С., Ньюман Дж. Корпусное исследование английских глаголов, обозначающих мыслительную деятельность, и их влияние на глаголы физической активности с элементами эпистемизации // Вестник Российского университета дружбы народов. Серия: Лингвистика. 2018. Т. 22. по 3. С. $560-580$. 
20. Труфанова И.В. Лексикографический портрет местоимения иной // Вестник Российского университета дружбы народов. Серия: Теория языка. Семиотика. Семантика. 2017. Т. 8. no 3. C. $509-518$.

21. Юдина Н.В. Терминология родственных отношений в русскоязычном дискурсе XXI века // Научное мнение. 2014. nо 8. С. 13-23.

22. Келли Дж.Дж. Практика применения дискурса в изучении и обучении наукам // Пособие по исследованию научной практики. Т. ІІ. Нью-Йорк, 2014. С. 321-336.

23. Мак-Комас В.Ф. Научный дискурс (риторика науки) // Научно-популярный язык. Роттердам, 2014.

24. Филясова Ю.А. Моделирование системы непрерывного и тематического контроля уровня развития иноязычной коммуникативной компетенции // Вестник Российского университета дружбы народов. Серия: Русский и иностранный языки и методика их преподавания. 2015. по 4. С. $210-223$.

25. Костин A.B. От информационного общества к цифровому // Человеческий капитал в формате цифровой экономики: междунар. науч. конф. 16 февр. 2018 г. М. С. $72-80$.

\section{Сведения об авторе:}

Филясова Юлия Анатольевна, кандидат филологических наук, доцент кафедры педагогики, психологии и переводоведения Санкт-Петербургского университета технологий управления и экономики (Россия); научные интересы: лингвистика, фонетика, деловой английский язык, медиадискурс, технический перевод, педагогика; e-mail: phill.yield@gmail.com; SPIN-код: 9503-8000, ORCID: https://orcid.org/0000-0002-9728-9458

\section{Information about the author:}

Yulia A. Filyasova, Candidate of Philological Sciences, Associate Professor of the Department of Pedagogy, Psychology and Translation Studies, Saint-Petersburg University of Management Technologies and Economics (Russia); scientific interests: linguistics, phonetics, business English, media discourse, technical translation, pedagogy; e-mail: phill.yield@gmail.com; ORCID: https://orcid.org/0000-0002-9728-9458

\section{Для цитирования:}

Филясова Ю.А. Английский экономический термин «человеческий капитал» и его семантическое поле в научном дискурсе // Вестник Российского университета дружбы народов. Серия: Теория языка. Семиотика. Семантика. Т. 10. № 3. С. 700-713. doi: 10.22363/2313-2299-201910-2-700-713.

\section{For citation:}

Filyasova, Yu.A. (2019). The English Economic Term 'Human Capital' and Its Semantic Field in Scientific Discourse. RUDN Journal of Language Studies, Semiotics and Semantics, 10 (3), 700 713. doi: 10.22363/2313-2299-2019-10-2-700-713. 